\title{
Sepsis, Phages, and COVID-19
}

\section{Andrzej Górski 1,2,3® , Jan Borysowski ${ }^{4, *}$ and Ryszard Międzybrodzki 1,2,4}

1 Bacteriophage Laboratory, Hirszfeld Institute of Immunology and Experimental Therapy, Polish Academy of Sciences (HIIET PAS), 53-114 Wrocław, Poland; agorski@ikp.pl (A.G.); ryszard.miedzybrodzki@hirszfeld.pl (R.M.)

2 Phage Therapy Unit, Hirszfeld Institute of Immunology and Experimental Therapy, Polish Academy of Sciences (HIIET PAS), 53-114 Wrocław, Poland

3 Department of Clinical Immunology, Infant Jesus Clinical Hospital, 02-006 Warsaw, Poland

4 Department of Clinical Immunology, Transplantation Institute, Medical University of Warsaw, 02-006 Warsaw, Poland

* Correspondence: jborysowski@interia.pl

Received: 21 August 2020; Accepted: 13 October 2020; Published: 15 October 2020

check for updates

\begin{abstract}
Phage therapy has emerged as a potential novel treatment of sepsis for which no decisive progress has been achieved thus far. Obviously, phages can help eradicate local bacterial infection and bacteremia that may occur in a syndrome. For example, phages may be helpful in correcting excessive inflammatory responses and aberrant immunity that occur in sepsis. Data from animal studies strongly suggest that phages may indeed be an efficient means of therapy for experimentally induced sepsis. In recent years, a number of reports have appeared describing the successful treatment of patients with sepsis. Moreover, novel data on the anti-viral potential of phages may be interpreted as suggesting that phages could be used as an adjunct therapy in severe COVID-19. Thus, clinical trials assessing the value of phage therapy in sepsis, including viral sepsis, are urgently needed.
\end{abstract}

Keywords: sepsis; phage; COVID-19

The World Health Organization (WHO) considers sepsis to be a global health priority. Recently, it has been emphasized that, despite some success in preclinical studies on experimental sepsis, no significant progress has been achieved in clinical therapy [1]. Although more than a hundred clinical trials have focused on sepsis, none of them have provided data that could be used for improvements or a cure [2]. Furthermore, the most recent data indicate that, despite best efforts to provide protocol-based care pathways, mortality from sepsis may reach nearly $40 \%$ [3].

Gaidelyte et al. showed that most of the sepsis-causing bacteria carry functional phages that are released and circulate in the blood of septicemic patients [4]. Those phages can lyse other isolates of the same bacterial strain but not the pathogenic strain in sepsis. Thus, those prophages play a role in clonal selection of pathogens in this disorder. At the same time, it appears reasonable that phage application may potentially be used in the treatment of sepsis based on both well-known anti-bacterial as well as non-bacterial activities of phages, especially those related to their anti-inflammatory and immunomodulating effects [2,5]. In fact, in addition to data obtained in experimental animals, there are already reports of successful phage therapy in patients with sepsis [2]. In this review, we summarize the progress in treating sepsis with phage therapy over the last three years.

\section{Phage Therapy of Experimentally Induced Sepsis}

Leshkasheli et al. demonstrated the therapeutic efficacy of phage therapy in Galleria mallonella larvae and in a mouse model of sepsis caused by Acinobacter baumanii [6]. Similar data were obtained by $\mathrm{Wu}$ et al., who showed that a phage effective against that pathogen can rescue lethal sepsis mice [7]. Interestingly, the effect of a single phage treatment $\left(1 \mathrm{~mL}\right.$ ip at a dose of $\left.10^{9}\right)$ was comparable 
to the effect of a phage cocktail containing 14 phages. In experiments performed by Wang et al., phage therapy applied concurrently with the inoculation of the pathogen rescued $100 \%$ of mice, whilst phage administration applied $1 \mathrm{~h}$ after inoculation with $A$. baumanii reduced survival to approx. $50 \%$ [8].

Phage therapy efficacy has also been studied in a mouse model of neonatal sepsis caused by Escherichia coli, Klebsiella pneumoniae, Haemophilus influenzae, Pseudomonas aeruginosa, Citrobacter freundii and Moraxella catarrhalis. A single intraperitoneal (ip) phage dose rescued $60-100 \%$ of mice depending on the phage dose. More detailed studies have revealed that a concentration as low as $0.01 \mathrm{MOI}$ (multiplicity of infection) was effective in rescuing $80 \%$ of mice, whilst a 0.001 MOI dose rescued only $20 \%$ of mice. Interestingly, the mice could be rescued even when phage administration was delayed for $24 \mathrm{~h}$ after pathogen inoculation. While both a single phage and phage cocktails were effective, optimal results have been achieved with cocktails [9].

High effectiveness of phage therapy in the treatment of experimental sepsis induced by multidrug resistant $P$. aeruginosa was also confirmed by Alvi et al. [10]. Phage-treated bacteremic mice had a survival rate of almost $100 \%$, and no viable pathogen could be detected at $96 \mathrm{~h}$ post inoculation. The authors estimate that, in order for therapy of sepsis to be efficient, phages should persist in the blood for at least 3-5 h. A native agarose gel electrophoresis was applied to assess phage surface associated with high blood persistence [11].

Phages have been shown to upregulate gene expression of an anti-inflammatory cytokine Il-R antagonist [12] and downregulate NF-kappa B signaling [13]. Interestingly, suppressing NF-kappa B signaling may be beneficial in an experimental mouse model of sepsis [14].

\section{Clinical Phage Therapy of Sepsis}

A 2-year-old boy with DiGeorge syndrome, recalcitrant $P$. aeruginosa bacteremia, and an allergy to antibiotics received a cocktail of two phages every $6 \mathrm{~h}$ intravenously (iv) for $36 \mathrm{~h}$. Treatment with antibiotics, including meropenem, tobramycin, and polymyxin B, was also continued. Blood cultures turned negative and then positive again after cessation of phage therapy. The therapy was subsequently resumed, and blood cultures were reverted to negative again. Thus, in this patient, phage therapy resulted in sterilization of the blood [15].

Jennes et al. described a patient with acute kidney injury complicated by septicemia caused by colistin-only sensitive $P$. aeruginosa and acute kidney failure. The patient received a $50 \mathrm{~mL}$ cocktail of two phages in a $6 \mathrm{~h}$ iv infusion for 10 days. Blood cultures turned negative immediately, C-reactive protein (CRP) dropped, fever disappeared, and renal function recovered [16].

Recently, Australian authors have reported results of adjunctive phage therapy (combined with antibiotics) of $S$. aureus bacteremia in 13 patients, most of whom suffered from infective endocarditis. A phage cocktail composed of three phages was administered twice daily for 14 days. A $10^{9}$ PFU infused phage dose yielded approx. $2 \times 10^{5} \mathrm{PFU} / \mathrm{mL}$ of blood, which suggests that such a dose may be adequate to achieve a desired therapeutic effect. The iv infusions were well tolerated; no fever, rashes, hypotension or other adverse reactions were observed. Clinical improvement was evident in eight of the 13 patients, and inflammation markers declined during or soon after the therapy [17].

Further progress in phage therapy of sepsis has recently been achieved by introducing engineered phages used to treat a patient with a disseminated drug resistant mycobacterial infection. Genome engineering and forward genetics were applied to obtain lytic phage derivatives that were infused iv as a three-phage cocktail ( $10^{9} \mathrm{PFU}$ per dose of each phage) twice daily for 32 weeks. Phage infusion was well tolerated, without significant side effects. Serum phage titers reached levels exceeding $10^{9} / \mathrm{mL}$. Weak anti-phage protein antibody responses were noted, but no evidence of phage neutralization was observed. The clinical condition of the patient improved while sterilization of the blood and sputum was achieved [18].

Sepsis is one of the principal causes of morbidity and mortality in neonates and young children in low and middle-income countries. Recently, scientists in Iraq have developed a cocktail of phages 
against pathogens implicated in neonatal sepsis in a Bagdad teaching hospital (E. coli, K. pneumoniae, H. influenzae, P. aeruginosa, C. freundii, and M. catarrhalis). The cocktail containing 29 phages showed activity against all bacterial hosts in vitro and should be further examined for its in vivo efficacy in experimental and clinical sepsis [19].

In summary, in animal studies, phages were administered ip at a dose of $10^{9}-10^{10}$, and the outcome was assessed as animal rescue and reduction of bacterial burden in organs or blood. In human studies, the outcome was assessed as a clinical improvement combined with laboratory signs (e.g., disappearance of fever, improvement in general patient well-being, improvement in organ function (e.g., renal function), drop of CRP, negative blood cultures). No significant adverse effects were observed in treated patients, which is in line with our data on large cohorts of patients [20]. Phage treatments elicit antibody responses; however, those serum antibodies do not appear to significantly influence the outcome of therapy [21]. On the other hand, it cannot be excluded that phage therapy also induces the formation of a phage-antibody immune complex. Therefore, the clinical significance of a humoral response to phages during the therapy requires further studies. Furthermore, more detailed studies on phage pharmacokinetics would be helpful for the advancement of phage therapy.

Recent data suggest that disturbances in the microbiome can enhance susceptibility to sepsis [1]. Interestingly, fecal microbiota transplantation (FMT) may rescue mice from human pathogen-mediated sepsis [22]. Additionally, FMT improves survival in sepsis induced in rats [23]. Notably, it has been suggested that transfer of phages may play a role in the efficacy of FMT [24,25]. Interestingly, a clinical trial of FMT for patients with COVID-19 is ongoing [26]. Moreover, promising results have been achieved in subgroups of septic patients treated with the Il-R antagonist ( 28 day mortality $34.6 \%$ vs. $64.7 \%$ placebo) [1]. In addition to the data presented earlier [2], these findings seem to strengthen arguments for the potential application of phages in the treatment of sepsis.

In addition to phages, phage-derived lytic enzymes (lysins) have also been studied as a potential weapon against multi-drug resistant bacteria. Recently, the results of a first placebo-controlled clinical trial involving an antistaphylococcal lysin (exebacase) administered in conjunction with antibiotics in patients with $S$. aureus septicemia (most with infectious endocarditis) have been published. In comparison to the control (antibiotics only), the exebacase group showed higher responder rates as well as a reduction in length of stay and readmission rates. No hypersensitivity reactions to exebacase were reported. Although preexisting anti-lysin antibodies were detectable in some patients, this did not affect the efficacy and the safety of treatment. These results offer the first tangible opportunity to improve clinical results and reduce mortality in staphylococcal sepsis using phage-derived lysin [27]. Table 1 summarizes the recent progress in successfully applying phages and lysin in experimental and clinical sepsis.

Table 1. Summary of recent data on successful application of phages and lysin in experimental and clinical sepsis. ip—intraperitoneal application; iv—intravenous application.

\begin{tabular}{|c|c|c|c|}
\hline Animal Model/Human Disease & Pathogen & $\begin{array}{c}\text { Route and Schedule of Phage } \\
\text { Administration }\end{array}$ & Reference \\
\hline $\begin{array}{l}\text { Galleria mellonella larvae } \\
\text { mouse }\end{array}$ & Acinetobacter baumannii & $\begin{array}{c}\text { single injection } \\
\text { single ip MOI of } 100\end{array}$ & [6] \\
\hline mouse & Acinetobacter baumannii & single ip $10^{9}$ & [7] \\
\hline mouse & $\begin{array}{c}\text { Acinetobacter baumannii } \\
\text { Escherichia coli, Klebsiella }\end{array}$ & single ip MOI of $0.1-10$ & [8] \\
\hline mouse & $\begin{array}{l}\text { pneumoniae, Haemophilus influenzae, } \\
\text { Pseudomonas aeruginosa, Citrobacter } \\
\text { freundii, Moraxella catarrhalis }\end{array}$ & single ip MOI of $0.001-2$ & [9] \\
\hline mouse & Pseudomonas aeruginosa & single ip $10^{9}$ & [10] \\
\hline Di George syndrome with septicemia & Pseudomonas aeruginosa & iv for 3 days $3 \times 10^{5}$ every $6 \mathrm{~h}$ & {$[15]$} \\
\hline Acute kidney failure with septicemia & Pseudomonas aeruginosa & $\begin{array}{l}\text { iv for } 10 \text { days concentration not } \\
\text { given }\end{array}$ & [16] \\
\hline Endocarditis with septicemia (13 patients) & Staphylococcus aureus & iv for 14 days & [17] \\
\hline
\end{tabular}




\section{COVID-19, Viral Sepsis, and Phages}

Severe acute respiratory syndrome coronavirus (SARS-CoV-2) probably originated from a virus that has been circulating in horseshoe bats for several decades. It was first detected in Wuhan, China, which suggests the existence of an intermediary (pangolin?) that facilitated transmission to humans. There were also hints that the virus escaped or was deliberately released from a local institute [28]. As of 30 September 2020 there have been almost 34 million COVID-19 cases worldwide with $>1$ million deaths, and $>25$ million patients have recovered [29]. It has been noted that severe COVID-19 patients may develop typical manifestations of septic shock with blood and respiratory tract cultures testing negative for bacteria and fungus. Therefore, viral sepsis could be responsible for clinical manifestations in those patients in whom systemic cytokine storm, lymphopenia, and thrombotic complications are usually detectable. Effective antiviral therapy combined with attempts to modulate the innate immune response and upgrade the adaptive immune response are recommended to improve the outcome [30-32]. In fact, antiviral and anti-inflammatory treatments may be effective early in the disease [33,34].

The lungs - the primary target organ of the SARS-Cov-2 virus-are relatively accessible to phages delivered by different routes, including oral administration. However, nasal or tracheal delivery are preferred to achieve sufficient in situ concentrations. Aerosol phage preparations as well as nebulized preparations may serve as the most efficient therapeutic applications [35].

Growing data suggests that phages may interfere with the pathogenic action of eukaryotic viruses [36]. This historical data has been supported by new findings indicating a protective action of the T4 phage on human lung epithelial cells infected with human adenovirus (Adv); furthermore, adsorption of Adv to human lung and kidney epithelial cells as well as viral replication was also inhibited [37]. New data suggest that cell layers of the body may be the major sink for administered phages; interestingly, lung epithelial cells show the highest accumulation of phages [38]. Moreover, the expression of Adv genes and synthesis of Adv DNA may also be downregulated by T4 and staphylococcal phages [39]. We hypothesized that phage therapy might be helpful in combatting COVID-19 [40]. Thus, it is known that CoV-expressing cells display markedly upregulated levels of reactive oxygen species (ROS), and high levels of ROS are observed in the lungs of patients with COVID-19 [41,42]. Phages downregulate ROS production induced by bacteria and endotoxins [20]. Lymphocytopenia is frequently found in COVID-19, while the virus is known to induce apoptosis [41,43]. Moreover, autopsies have revealed atrophy of the spleen and the lymph nodes [44]. Interestingly, phages may reduce apoptosis of human airway epithelial cells when cultured in vitro [45]. In addition, Sweere et al. demonstrated that Pf phages cause upregulation of interferon (IFN) alpha and Il-12, thus promoting an antiviral signature in the lungs of mice [46]; Gogokhia et al. found that phages of Lactobacillus, E. coli and Bacteroides stimulate production of another potent antiviral cytokine, IFN gamma [47].

Recently, we showed that the T4 phage induces upregulation of the human defensin 2 gene (hBD2) [48]. This peptide, which is exposed primarily by epithelial cells, reduces viral replication and may enhance pathways responsible for other anti-microbial effects, both anti-bacterial and anti-viral. hBD2 activates primary anti-viral innate immune responses [49]. It suppresses HIV infection of HeLa cells in vitro [50], drastically reduces human respiratory syncytial virus (HRSV) infection of human lung epithelial cells [51], and inhibits the infectivity of HIV virions of human tonsil epithelial cells [52]. Thus, defensins have been shown to participate in antimicrobial defenses in the human respiratory tract, and the up-regulation of hBD2 may enhance those defenses [53]. Therefore, T4-induced hBD2 could also be engaged in mediating anti-SARS-CoV-2 defenses, which requires experimental confirmation.

An inflammatory response causes activation of the hemostatic system (endothelial and platelet activation and coagulation promoting thrombosis) - a syndrome also referred to as thromboinflammation which is relevant in COVID-19 [54]. In fact, thrombocytopenia is associated with increased risk of severe disease [55]. Platelets are known to interact with viruses and have recently been shown to be transient carriers of HIV, thus contributing to HIV dissemination by propagating the virus 
to macrophages. This process could be prevented by the anti-integrin alphaIlb/beta3 antibody [56]. Coronaviruses may also infect bone marrow cells [55]. SARS-CoV RNA may be present in platelets of COVID-19 patients, which suggests that platelets can participate in the dissemination of the virus [57]. It would be of interest to determine if this phenomenon could also be blocked by the anti-alphaIlb/beta3 antibody, which has been effective in preventing HIV dissemination. The alphaIlb/beta3 integrin binds specifically to a KGD (Lys-Gly-Asp) sequence motif exposed on the gp24 capsid protein of T4 phages. Therefore, T4 phages could interfere with platelet-dependent SARS-CoV dissemination, mimicking the effect of the anti-alphaIIb/beta3 antibody. In fact, it has been demonstrated that such interference could enable T4 phages to reduce the adhesion of platelets to fibrinogen [13].

Interestingly, there appears to be another target for anti-COVID-19 effects of phages. SARS-CoV-2 binds to its receptor, angiotensin-converting enzyme 2 (ACE2), through the receptor-binding domain (RBD) present in its major structural protein spike. Recently, an exposed KGD motif has been identified in ACE2, thus enabling it to interact with integrin alphaIlb/beta3 [58]. Therefore, platelets could associate with the SARS-CoV-2-ACE2 complex using their alphaIIb/beta3 integrin receptor targeting the KGD sequence present within the ACE2 molecule. This phenomenon could contribute to SARS-CoV-2 dissemination and upregulate platelet-mediated coagulopathy and tissue injury. The presence of platelet-fibrin thrombi is common in lung lesions in patients with COVID-19 and is considered to be the main target of therapy [59]. Occupation of the platelet alphaIlb/beta 3 integrin receptor by the phage KGD could inhibit platelet engagement with the complex formed by the virus and its receptor and prevent the ensuing pathology.

\section{Conclusions}

In recent years, a number of reports derived from experimental studies in animals and human clinics have suggested the potential value of phage therapy in the treatment of sepsis. The activity of both anti-bacterial and non-bacterial phages is relevant for successful phage therapy. The anti-inflammatory and the immunomodulating properties of phages could also be useful in the treatment of severe COVID-19 syndrome including viral sepsis (Table 2). A recent article from China concludes that phage therapy in sepsis treatment can be expected in the near future [60]. The data discussed in this review support this assumption. As pointed out, relevant clinical trials assessing the therapeutic value of phage therapy in those clinical settings are urgently needed [40].

Table 2. The relevant targets by which phage therapy may be applicable for treatment of COVID-19.

1. Phages can interact with epithelial cells and protect those cells from virus-induced damage and apoptosis; this could be especially relevant for lung epithelial cells.

2. Phages may prevent viral adsorption to epithelial cells and downregulate viral replication in those cells.

3. Phages may induce production of cellular chaperones protecting cells from viral injury (e.g., induction of Hsp70 in human alveolar cells).

4. Phages inhibit inflammation (downregulation of Nuclear Factor (NF) kappa B and reactive oxygen species (ROS) production).

5. Phages induce anti-viral immunity (e.g., induction of interferon (IFN)-alpha and IFN-gamma, defensin 2 and inhibition of Hsp90).

6. Phages may interfere with severe acute respiratory syndrome coronavirus (SARS-CoV)-b2 binding to angiotensin-converting enzyme 2 (ACE2).

Author Contributions: A.G. wrote the major part of the manuscript. A.G., J.B., and R.M. contributed to the conceptualization and reviewed the manuscript. All authors have read and agreed to the published version of the manuscript.

Funding: This work was supported by statutory funds of the Institute of Immunology and Experimental Therapy, Wrocław, Poland (501-16).

Conflicts of Interest: A.G., R.M., and J.B. are co-inventors of patents owned by the Institute and covering phage preparations. 


\section{References}

1. Cavaillon, J.M.; Singer, M.; Skirecki, T. Sepsis therapies: Learning from 30 years of failure of translational research to propose new leads. EMBO Mol. Med. 2020, 12, e10128. [CrossRef] [PubMed]

2. Górski, A.; Jończyk-Matysiak, E.; Łusiak-Szelachowska, M.; Międzybrodzki, R.; Weber-Dabrowska, B.; Borysowski, J. The potential of phage therapy in sepsis. Front. Immunol. 2017, 8, 1783. [CrossRef] [PubMed]

3. Font, M.D.; Thyagarajan, B.; Khanna, A.K. Sepsis and septic shock-Basics of diagnosis, pathophysiology and clinical decision making. Med. Clin. N. Am. 2020, 104, 573-585. [CrossRef] [PubMed]

4. Gaidelyte, A.; Vaara, M.; Bamford, D.H. Bacteria, phages and septicemia. PLoS ONE 2007, 2, e1145. [CrossRef] [PubMed]

5. Górski, A.; Międzybrodzki, R.; Węgrzyn, G.; Jończyk-Matysiak, E.; Borysowski, J.; Weber-Dąbrowska, B. Phage therapy: Current status and perspectives. Med. Res. Rev. 2020, 40, 459-463. [CrossRef]

6. Leshkasheli, L.; Kutateladze, M.; Balarjishvili, N.; Bolkvadze, D.; Save, J.; Oechslin, F.; Que, Y.A. Efficacy of newly isolated and highly potent bacteriophages in a mouse model of extensively drug-resistant Acinetobacter baumannii bacteraemia. J. Glob. Antimicrob. Res. 2019, 19, 255-261. [CrossRef]

7. Wu, M.; Hu, K.; Xie, Y.; Liu, Y.; Mu, D.; Guo, H.; Zhang, Z.; Zhang, Y.; Chang, D.; Shi, Y. A novel phage PD-6A3, and its endolysin Ply6A3, with extended lytic activity against Acinetobacter baumannii. Front. Microbiol. 2019, 9, 3302. [CrossRef]

8. Wang, J.L.; Kuo, C.F.; Yeh, C.M.; Chen, J.-R.; Cheng, M.-F.; Hung, C.-H. Efficacy of $\varphi$ km18p phage therapy in a murine model of extensively drug-resistant Acinetobacter baumannii infection. Infect. Drug Res. 2018, 2301-2310. [CrossRef]

9. Kaabi, S.; Musafer, H.K. An experimental mouse model for phage therapy of bacterial pathogens causing bacteremia. Microb. Path. 2019, 137, 103770. [CrossRef]

10. Alvi, I.A.; Asif, M.l; Tabassum, R.; Aslam, R.; Abbas, Z.; Rehman ur, S. RLP, a bacteriophage of the family Podoviridae, rescues mice from bacteremia caused by multi-drug-resistant Pseudomonas aeruginosa. Arch. Virol. 2020, 165, 1289-1297. [CrossRef]

11. Serwer, P.; Wright, E.T.; Lee, J.C. High murine blood persistence of phage T3 and suggested strategy for phage therapy. BMC Res. Notes 2019, 12, 560. [CrossRef]

12. Van Belleghem, J.D.; Clement, F.; Merabishvili, M.; Lavigne, R.; Vaneechoutte, M. Pro- and anti-inflammatory responses of peripheral blood mononuclear cells induced by Staphylococcus aureus and Pseudomonas aeruginosa phages. Sci. Rep. 2017, 7, 8004. [CrossRef] [PubMed]

13. Górski, A.; Dąbrowska, K.; Międzybrodzki, R.; Weber-Dąbrowska, B.; Łusiak-Szelachowska, M.; Jończyk-Matysiak, E.; Borysowski, J. Phages and immunomodulation. Future Microbiol. 2017, 12, 905-914. [CrossRef] [PubMed]

14. Wang, L.; Liang, Q.; Lin, A.; Chen, X.; Wu, Y.; Zhang, B.; Zhang, Y.; Min, H.; Wen, Y.; Song, S.; et al. Puerarin increases survival and protects against organ injury by suppressing NF- $\mathrm{B} / \mathrm{JNK}$ signaling in experimental sepsis. Front. Pharmacol. 2020, 11, 560. [CrossRef] [PubMed]

15. Duplessis, C.; Biswas, B.; Hanisch, B.; Perkins, M.; Henry, M.; Quinones, J.; Wolfe, D.; Estrella, L.; Hamilton, T. Refractory pseudomonas bacteremia in a 2-year-old sterilized by bacteriophage therapy. J. Ped. Infect. Dis. Soc. 2018, 7, 253-256. [CrossRef] [PubMed]

16. Jennes, S.; Merabishvili, M.; Soentjens, P.; Win Pang, K.; Rose, T.; Keersebilck, E.; Soete, O.; Francois, P.-M.; Teodorescu, S.; Verween, G.; et al. Use of bacteriophages in the treatment of colistin-only-sensitive Pseudomonas aeruginosa septicaemia in a patient with acute kidney injury-A case report. Crit. Care 2017, 21, 129. [CrossRef] [PubMed]

17. Petrovic, F.A.; Lin, R.; Ho, J.; Maddocks, S.; Ben Zakour, N.L.; Iredell, J.R. Safety of bacteriophage therapy in severe Staphylococcus aureus infection. Nat. Microbiol. 2020, 5, 465-472. [CrossRef]

18. Dedrick, R.M.; Guerrero-Bustamante, C.A.; Garlena, R.A.; Russell, D.A.; Ford, K.; Harris, K.; Gilmour, K.C.; Soothill, J.; Jacobs-Sera, D.; Schooley, R.T.; et al. Engineered bacteriophages for treatment of a patient with a disseminated drug-resistant Mycobacterium abscessus. Nat. Med. 2019, 25, 730-733. [CrossRef]

19. Kaabi, S.; Musafer, H.K. New Phage cocktail against infantile sepsis bacteria. Microb. Path. 2020, 148, 104447. [CrossRef] 
20. Międzybrodzki, R.; Borysowski, J.; Weber-Dąbrowska, B.; Fortuna, W.; Letkiewicz, S.; Szufnarowski, K.; Pawełczyk, Z.; Rogóż, P.; Kłak, M.; Wojtasik, E.; et al. Clinical aspects of phage therapy. Adv. Virus Res. 2012, 83, 73-121. [CrossRef]

21. Łusiak-Szelachowska, M.; Żaczek, M.; Weber-Dabrowska, B.; Międzybrodzki, R.; Letkiewicz, S.; Fortuna, W.; Rogóż, P.; Szufnarowski, K.; Jończyk-Matysiak, E.; Olchawa, E.; et al. Antiphage activity of sera during phage therapy in relation to its outcome. Future Microbiol. 2017, 12, 109-117. [CrossRef]

22. Kim, S.M.; DeFazio, J.R.; Hyoju, S.K.; Sangani, K.; Keskey, R.; Krezalek, M.A.; Khodarev, N.N.; Sangwan, N.; Christley, S.; Harris, K.G.; et al. Fecal microbiota transplant rescues mice from human pathogen mediated sepsis by restoring systemic immunity. Nat. Comm. 2020, 11, 2354. [CrossRef]

23. Assimakopoulos, S.F.; Papadopoulou, I.; Bantouna, D.; de Lastic, A.-N.; Rodi, M.; Mouzaki, A.; Gogos, C.A.; Zolota, V.; Maroulis, I. Fecal microbiota transplantation and hydrocortisone ameliorate intestinal barrier dysfunction and improve survival in a rat model of cecal ligation and puncture-induced sepsis. Shock 2020. [CrossRef]

24. Zuo, T.; Wong, S.H.; Lam, K.; Lui, R.; Cheung, K.; Tang, W.; Ching, J.Y.L.; Chan, P.K.S.; Chan, M.C.W.; $\mathrm{Wu}$, J.C.Y. Bacteriophage transfer during faecal microbiota transplantation in Clostridium difficile infection is associated with treatment outcome. Gut 2018, 67, 634-643. [CrossRef]

25. Draper, L.A.; Ryan, F.J.; Smith, M.K.; Jalanka, J.; Mattila, E.; Arkkila, P.A.; Ross, R.P.; Satokari, R.; Hill, C. Long-term colonisation with donor bacteriophages following successful faecal microbial transplantation. Microbiome 2018, 6, 220. [CrossRef]

26. He, Y.; Wang, J.; Li, F.; Shi, Y. Main Clinical Features of COVID-19 and potential prognostic and therapeutic value of the microbiota in SARS-CoV-2 infections. Front. Microbiol. 2020, 11, 1302. [CrossRef]

27. Fowler, V.G., Jr.; Das, A.F.; Lipka-Diamond, J.; Schuch, R.; Pomerantz, R.; Jaruegui-Peredo, L.; Bressler, A.; Evans, D.; Moran, G.J.; Rupp, M.E.; et al. Exebacase for patients with Staphylococcus aureus bloodstream infection and endocarditis. J. Clin. Investig. 2020, 130, 3750-3760. [CrossRef] [PubMed]

28. Burki, T. The origin of SARS-CoV-2. Lancet Infect. Dis. 2020, 20, 1018-1019. [CrossRef]

29. COVID-19 Coronavirus Pandemic. Available online: https://www.worldometers.info/coronavirus/?\# countries (accessed on 1 October 2020).

30. Li, H.; Liu, L.; Zhang, D.; Xu, J.; Dai, H.; Tang, N.; Su, X.; Cao, B. SARS-CoV-2 and viral sepsis: Observations and hypotheses. Lancet 2020, 395, 1517-1520. [CrossRef]

31. Dallan, C.; Romano, F.; Siebert, J.; Politi, S.; Lacroix, L.; Sahyoun, C. Septic shock presentation in adolescents with COVID-19. Lancet Child Adolesc. Health 2020, 4, e21-e23. [CrossRef]

32. Ren, D.; Ren, C.; Yao, R.Q.; Feng, Y.-W.; Yao, Y.-M. Clinical features and development of sepsis in patients infected with SARS-CoV-2: A retrospective analysis of 150 cases outside Wuhan, China. Int. Care Med. 2020, 1-4. [CrossRef]

33. Anonymous. The Lancet Haematology COVID-19 coagulopathy: An evolving story. Lancet Haematol. 2020, 7, e425. [CrossRef]

34. Remy, K.E.; Brakenridge, S.C.; Francois, B.; Daix, T.; Deutschman, C.S.; Monneret, G. Immunotherapies for COVID-19: Lessons learned from sepsis. Lancet Respir. Med. 2020. [CrossRef]

35. Huh, H.; Wong, S.; St Jean, J.; Slavcev, R. Bacteriophage interactions with mammalian tissue: Therapeutic applications. Adv. Drug Deliv. Rev. 2019, 145, 4-17. [CrossRef] [PubMed]

36. Miedzybrodzki, R.; Fortuna, W.; Weber-Dabrowska, B.; Gorski, A. Bacterial viruses against viruses pathogenic for man? Virus Res. 2005, 110, 1-8. [CrossRef] [PubMed]

37. Przybylski, M.; Borysowski, J.; Jakubowska-Zahorska, R.; Weber-Dąbrowska, B.; Górski, A. T4 bacteriophagemediated inhibition of adsorption and replication of human adenovirus in vitro. Future Microbiol. 2015, 10, 453-460. [CrossRef]

38. Bichet, M.C.; Chin, W.H.; Richards, W.; Lin, Y.-W.; Avellaneda-Franco, L.; Hernandez, C.A.; Oddo, A.; Chernyavskiy, O.; Hilsenstein, V.; Neild, A.; et al. Bacteriophage uptake by eukaryotic cell layers represents a major sink for phagesduring therapy. BioRxiv 2020, in press.

39. Przybylski, M.; Dzieciątkowski, T.; Borysowski, J.; Międzybrodzki, R.; Górski, A. Inhibitory effects of bacteriophage preparations on adenoviral replication. Intervirology 2019, 62, 37-44. [CrossRef]

40. Górski, A.; Międzybrodzki, R.; Żaczek, M.; Borysowski, J. Phages in the fight against COVID-19? Future Microbiol. 2020, in press. 
41. Lin, C.W.; Lin, K.H.; Hsieh, T.H.; Shiu, S.Y.; Li, J.Y. Severe acute respiratory syndrome coronavirus 3C-like protease-induced apoptosis. FEMS Immunol. Med. Microbiol. 2006, 46, 375-380. [CrossRef]

42. Kim, E.S.; Chin, B.S.; Kang, C.K.; Kim, N.J.; Kang, Y.M.; Choi, J.P.; Oh, D.H.; Kim, J.H.; Koh, B.; Kim, S.E. Clinical course and outcomes of patients with severe acute respiratory syndrome coronavirus 2 infection: A preliminary report of the first 28 patients from the Korean cohort study on COVID-19. J. Korean Med. Sci. 2020, 35, e142. [CrossRef]

43. Wang, L.; He, W.; Yu, X.; Hu, D.; Bao, M.; Liu, H.; Zhou, J.; Jiang, A. Coronavirus disease 2019 in elderly patients: Characteristics and prognostic factors based on 4-week follow-up. J. Infect. 2020, 80, 639-645. [CrossRef] [PubMed]

44. Zhang, W.; Zhao, Y.; Zhang, F.; Wang, Q.; Li, T.; Liu, Z.; Wang, J.; Quin, Y.; Zhang, X.; Yan, X. The use of anti-inflammatory drugs in the treatment of people with severe coronavirus disease 2019 (COVID-19): The Perspectives of clinical immunologists from China. Clin. Immunol. 2020, 214, 108393. [CrossRef]

45. Trend, S.; Chang, B.J.; O’Dea, M.; Stick, S.M.; Kicic, A. Use of a primary epithelial cell screening tool to investigate phage therapy in cystic fibrosis. Front. Pharmacol. 2018, 9, 1330. [CrossRef] [PubMed]

46. Sweere, J.M.; van Belleghem, J.D.; Ishak, H.; Bach, M.S.; Popescu, M.; Sunkari, V.; Kaber, G.; Manasherob, R.; Suh, G.A.; Cao, X. Bacteriophage trigger antiviral immunity and prevent clearance of bacterial infection. Science 2019, 363, eaat9691. [CrossRef] [PubMed]

47. Gogokhia, L.; Buhrke, K.; Bell, R.; Hoffman, B.; Garrett Brown, D.; Hanke-Gogokhia, C.; Ajami, N.J.; Wong, M.C.; Ghazaryan, A.; Valentine, J.F.; et al. Expansion of bacteriophages is linked to aggravated intestinal inflammation and colitis. Cell Host Microbe. 2019, 25, 285-299. [CrossRef] [PubMed]

48. Borysowski, J.; Międzybrodzki, R.; Przybylski, M.; Owczarek, B.; Weber-Dabrowska, B.; Górski, A. The effects of T4 and A5/80 phages on the expression of immunologically important genes in differentiated Caco-2 cells. Adv. Hyg. Med. Exp. 2020, 74, 371-376. [CrossRef]

49. Kim, J.; Yang, Y.L.; Jang, S.H.; Jang, Y.S. Human $\beta$-defensin 2 plays a regulatory role in innate antiviral immunity and is capable of potentiating the induction of antigen-specific immunity. Virol. J. 2018, 15, 124. [CrossRef]

50. Sun, L.; Finnegan, C.M.; Kish-Catalone, T.; Blumenthal, R.; Garzino-Demo, P.; La Terra Maggiore, G.M.; Berrone, S.; Kleinman, C.; Wu, Z.; Abdelwahab, S.; et al. Human beta-defensins suppress human immunodeficiency virus infection: Potential role in mucosal protection. J. Virol. 2005, 79, 14318-14329. [CrossRef]

51. Kota, S.; Sabbah, A.; Chang, T.H.; Harnack, R.; Xiang, Y.; Meng, X.; Bose, S. Role of human beta-defensin-2 during tumor necrosis factor-alpha/NF-kappaB-mediated innate antiviral response against human respiratory syncytial virus. J. Biol. Chem. 2008, 283, 22417-22429. [CrossRef]

52. Herrera, R.; Morris, M.; Rosbe, K.; Feng, Z.; Weinberg, A.; Tugizov, S. Human beta-defensins 2 and -3 cointernalize with human immunodeficiency virus via heparan sulfate proteoglycans and reduce infectivity of intracellular virions in tonsil epithelial cells. Virology 2016, 487, 172-187. [CrossRef]

53. Meade, K.G.; O'Farrelly, C. $\beta$-Defensins: Farming the Microbiome for Homeostasis and Health. Front. Immunol. 2019, 9, 3072. [CrossRef] [PubMed]

54. Páramo, J.A. Inflammatory response in relation to COVID-19 and other prothrombotic phenotypes. Reumatol. Clin. 2020. [CrossRef]

55. Lippi, G.; Plebani, M.; Henry, B.M. Thrombocytopenia is associated with severe coronavirus disease 2019 (COVID-19) infections: A meta-analysis. Clin. Chim. Acta 2020, 506, 145-148. [CrossRef]

56. Real, F.; Capron, C.; Sennepin, A.; Arrigucci, R.; Zhu, A.; Sannier, G.; Zheng, J.; Xu, L.; Masse, J.-M.; Greffe, S.; et al. Platelets from HIV-infected individuals on antiretroviral drug therapy with poor CD4+ T cell recovery can harbor replication-competent HIV despite viral suppression. Sci. Transl. Med. 2020, 12, eaat6263. [CrossRef] [PubMed]

57. Manne, B.K.; Denorme, F.; Middleton, E.A.; Portier, I.; Rowley, J.W.; Stubben, C.; Petrey, A.C.; Tolley, N.D.; Guo, L.; Cody, M.; et al. Platelet gene expression and function in COVID-19 patients. Blood 2020. [CrossRef]

58. Luan, J.; Lu, Y.; Gao, S.; Zhang, L. A potential inhibitory role for integrin in the receptor targeting of SARS-CoV-2. J. Infect. 2020. [CrossRef]

59. Carsana, L.; Sonzogni, A.; Nasr, A.; Rossi, R.S.; Pellegrinelli, A.; Zerbi, P.; Rech, R.; Colombo, R.; Antinori, S.; Corbellino, M.; et al. Pulmonary post-mortem findings in a series of COVID-19 cases from northern Italy: A two-centre descriptive study. Lancet Infect. Dis. 2020. [CrossRef] 
60. Peng, Y.Z.; Yang, Z.C. Effects of phage therapy on sepsis. Zhonghua Shao Shang Za Zhi 2020, 36, 5-8. (In Chinese) [CrossRef]

Publisher's Note: MDPI stays neutral with regard to jurisdictional claims in published maps and institutional affiliations.

(C) 2020 by the authors. Licensee MDPI, Basel, Switzerland. This article is an open access article distributed under the terms and conditions of the Creative Commons Attribution (CC BY) license (http://creativecommons.org/licenses/by/4.0/). 